\title{
APPLICATION OF REMOTE SENSING AND AIRBORNE SPECTROMETRIC DATA ANALYSIS TO DELINEATE THE ALTERATION ZONES AT GABAL SUWAYQAT AREA CENTRAL EASTERN DESERT, EGYPT
}

\author{
Bayoumi, M. B. \\ Nuclear Materials Authority (NMA), Cairo, Egypt. \\ P.O.B.530 Maadi, Cairo, Egypt. Email: Moustafanma@yahoo.com
}

\begin{abstract}
The present study aims to study the potentiality of promised radioactive zones in the granitic rocks at Gable Suwayqat area. The Processed Landsat ETM+ data false color composite image (FCC) band 7, 4, 2 in $\mathrm{RGB}$, band ratios $(5 / 7,4 / 3,3 / 1),(5 / 7,5 / 1,4),(3 / 1,5 / 4,7 / 5)$ in red green blue and 5/7 in gray color. Principal component analysis (Pc2, Pc3, Pc5) in RGB were prepared for discriminating rock unites. Verified by the fieldwork and airborne gamma- ray spectrometric surveyed data enabled to differentiate the acidic and mafic rocks, and identified the alteration zones in the granitic rocks, which were effectively distinguished into high felsic and low ferromagnesian mineral contents, relative to the other granite areas.

The gamma-ray spectrometric interpretations reveal that most of radiometric anomalies recorded at north eastern and south western sides of study area. The structural framework and consequent surface features controled and managed the distribution and localization of the radioactive elements and the environmental dose rates in the area. The high fractures density act as good channels and passages for the mineral bearing hydrothermal ascending fluids and the percolating meteoric water that leached uranium mineralization and redeposited it in the adjacent fractured sites. Such processes in the granitic masses may be responsible for the presence of uranium and thorium mineralizations in these granites. The calculated dose rates range between 0.1 and $1.1 \mathrm{~m} \mathrm{~Sv} / y e a r$, indicating that the study area remains safe and under the maximum permissible safe radiation dose rate without harm to the individual, with continuous external irradiation of the whole body. The results show that the target area has some $\mathrm{eU}$, eTh, and $\mathrm{K} \%$ anomalies related to the biotite granites and are structurally controlled by the dominated faults.
\end{abstract}

Keywords: Landsat ETM+, Gamma-ray spectrometric, Dose rate, uranium mineralization, alteration zones, quartz veins, Eastern Desert

\section{INTRODUCTION}

The Central Eastern Desert of Egypt (where the study area sets) is a part of the Pan African Arabian-Nubian Shield (ANS) that was discussed and described by many authors as a tectonized regime involving complicated geologic processes producing mineralizing fluids as sources for ore deposition when expelled from the deeper parts of an orogen (Oliver, 1986; Nesbitt,1992; Garven et al., 1999). Johnson et al. (2011) studied the history of the ANS regarding to the depositional plutonic structural and tectonic events associated with the closing stages of the northeast African orogen. The Central Eastern Desert is known for its numerous ore mineral occurrences as it includes a variety of geological environments favorable to mineral ore formation. Each rock or rock assemblage characterizes a specific mineral or group of minerals, which is determined by a specific genesis. The image processing of the Satellite images can provide detailed information on the discrimination of the rock types and have been used to map rocks, mineral assemblages and weathering characteristics (Rowan et al, 1974).

The remote sensing approaches for geological mapping and mineral exploration are based on the physical characteristics and spectral signatures differences of the minerals and rocks which be assigned as varied tones reflecting different geological and structural features on the images. The remote sensing data of the study area were processed for lithological discrimination of the uraniferous granites and associated alteration 
Bayoumi, M. B.

zones. Several image processing approaches including false-color composite image $(7,4,2)$ in the red green blue (RGB) and band ratio images $(3 / 1,5 / 4,5 / 7),(3 / 1,4 / 3,5 / 7)$ and principal component $(\mathrm{Pc} 2, \mathrm{Pc} 3$, Pc5) in R, G, B was used because they contain most of the geological information for the lithological discrimination and mapping of the uraniferous alteration zones in the study area. Landsat ETM+ band-ratio 5/7 maps clay alteration because the clay minerals, such as kaolinite, montmorillonite, illite, and alunite, have reflectance maxima within band 5 and reflectance minima within band 7 (Sabins, 1997). Band ratios are useful for the qualitative detection of hydrothermal alteration minerals and are widely applied in geological and mineral mapping in the Eastern Desert of Egypt (e.g., Di Tommaso and Rubinstein, 2007). The integration of remote sensing and gamma-ray spectrometric interpretations reveals that most of radiometric anomalies recorded western side of Wadi (W.) Mubarak belt. The area is bounded by latitudes $25^{\circ} 16^{\prime} 30^{\prime \prime}-25^{\circ} 26^{\prime} 30^{\prime \prime} \mathrm{N}$ and longitudes $34^{\circ} 7^{\prime}-34^{\circ} 19^{\prime} 30^{\prime \prime} \mathrm{E}$ (Fig. 1).

The study area is covered with basement rocks, and it is dissected by numerous wadis trending in the NW-SE, NE-SW, and E-W directions, in harmony with the trends of the major faults. The present study aims to throw light to any relation between the distributions of the radioactive elements and rock types, and determine the environmental dose rates in the study area. Airborne radio spectrometric survey has been used in the study area in order to investigate the distribution of the three radioelements, $\mathrm{K} \%$, eU, and $\mathrm{eTh}$, as well as the total count radiation, nature of the distributions of the three radioelements is very common in weak zones such as shear zones, faults, fractures, and dikes. These data are subjected to many processes including the statistical treatment where the environmental effect as dose rate is calculated, which is one of our main targets in this study. The purpose of this study is to spot light on the importance of using remote sensing and Airborne gamma ray spectrometric techniques for discrimination between rock types as well as to explain the best conditions for exploration for radioactive mineralizations.

Fig. 1: Location map for study area ( $\square$ Study area).

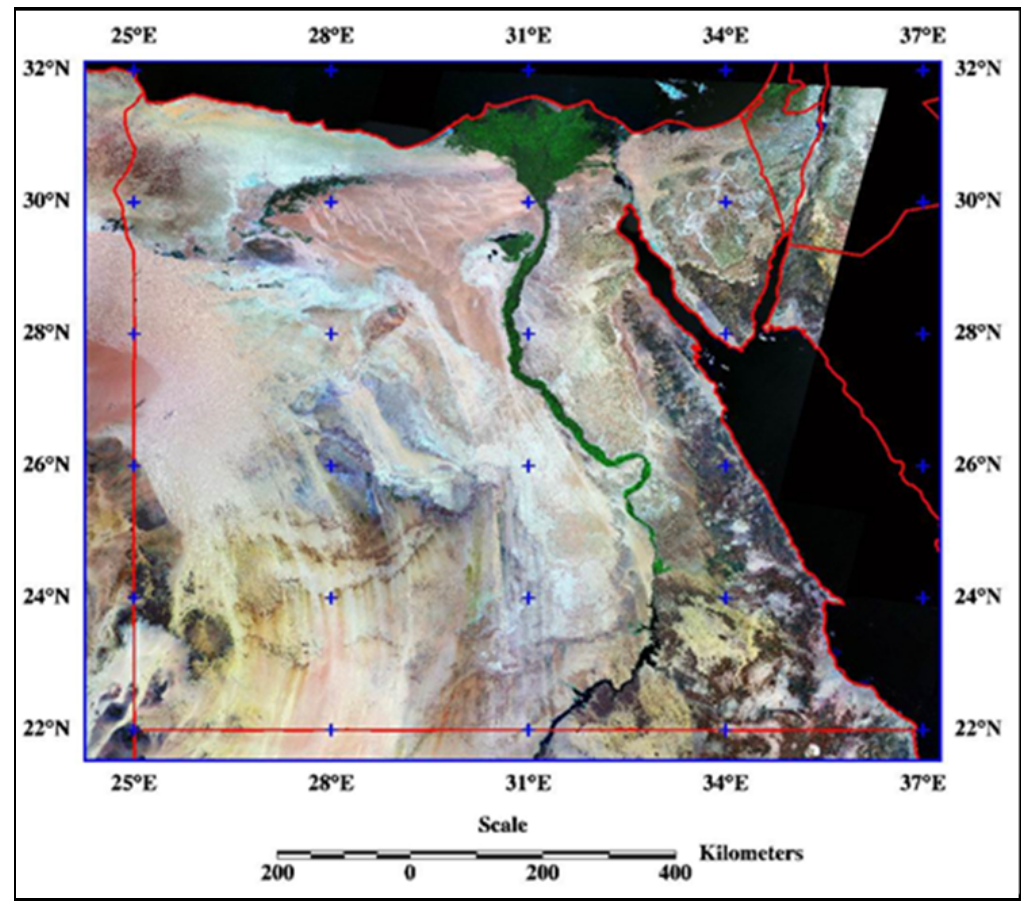

\section{Geologic setting}

The basement rocks in the study area are represented by serpentinites and related rocks, metagabbrodiorite complex, acidic to basic metavolcanics, metasediments, and gray gran- ites. The whole sequence is intruded by different late-to-post tectonic plutonites (younger granites). The recent sediments (Quaternary Wadi and Terrace sediments) cover all the coastal plain and wadis (Fig. 2). The exposed rocks belong mostly to the Late Precambrian passing to Early Paleozoic, except the Phanerozoic foreland volcanics, which could be of Mesozoic age (Elshazly 1977). There are some occurrences of mineral deposits in Gabal Suwayqat area in 
the Eestern part of the study area as metamorphosed ore deposits. The area is folded and frequent faults truncate the bands. The main ore is a black magnetite ore; however, carbonate bearing or jaspilitic ores are also present. The area covers the largest area of Wadi Mobark belt from the western side; it is characterized by both gentle and rough topographies. It is traversed by many wadis (dry valleys), which trend in a NE-SW direction as Wadi W. Um Geheig and W. Abu Eligam and in NW-SE as Khur Um Safi and W. Almyit (Fig. 2). Many landmarks exist in the area under con- sideration; the most important of which are G. Al Umarah $(787 \mathrm{~m})$, G. Suwayqat, G. Elhadid (680 m), G. Atwani, and the north part of G. Bakrah (901 m). The geological map of the area under study, scale 1:100,000 (Fig. 2), was compiled from Gabal Um Gheig quadrangle geological map, 1989 of the Egyptian Geological Survey and Mining Authority (EGSMA). The area under consideration was reported in the geophysical studies by many authors (Abdelhadi 1978; Rabie and Ammar 1990; Kamel and Abdelhadi 1992 and Elnaga, et al (2015).

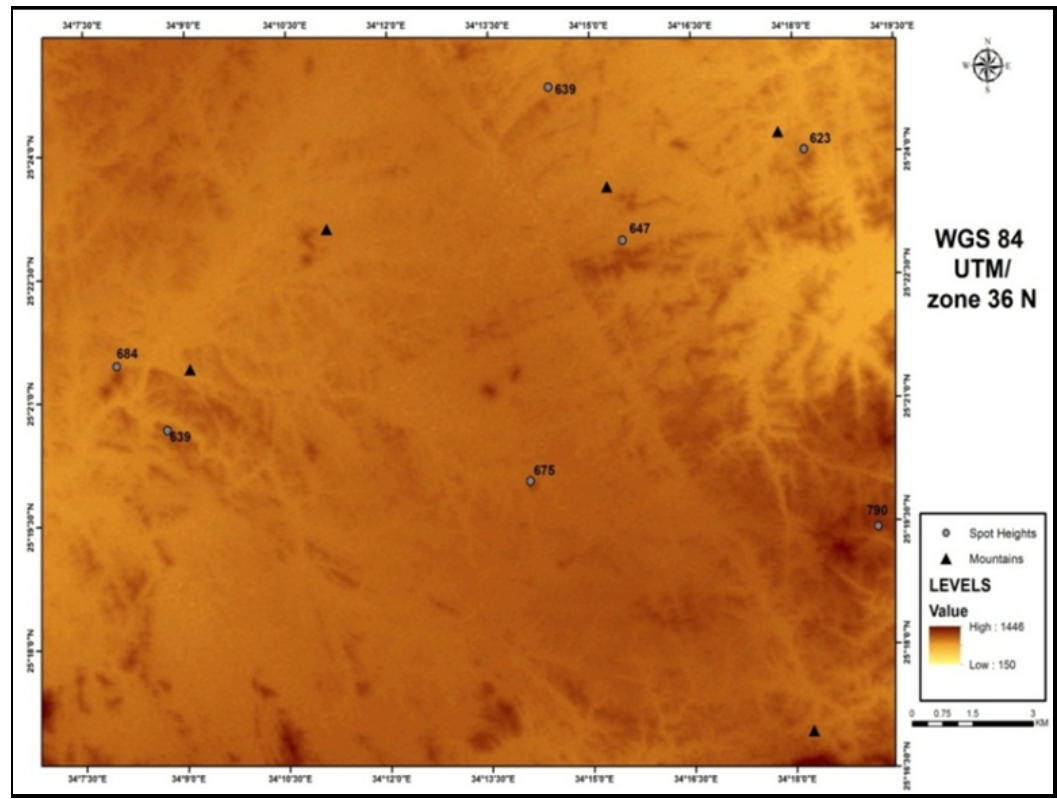

METHODOLOGY
Fig. 2: Topographic elevation and physiographic maps of Gabal Suwayqat area, Central Eastern Desert, Egypt.

\section{Remote sensing techniques}

The Landsat 8, One scene (Path 174/ Row 042 was acquired in 2005) covering the study area. It has been preprocessed and prepared for data extraction by geometry and radiometry correction as well as noise removing and UTM georeferencing. These approaches were performed using Envi v.4.5 software and Arc GIS v. 10.3 for generating and layout the processed images.

\section{Geophysical data processing techniques}

The available airborne spectrometric data scale 1:50,000, were surveyed by Aero-Service Division, Western Geophysical Company of America, USA, in 1984 (Aero-Service 1984). The survey was conducted at a flight altitude of $120 \mathrm{~m}$ terrain clearance, $1.5 \mathrm{~km}$ of flight line interval, and $10 \mathrm{~km}$ of tie line spacing. These data have been prepared for subsequent processing by digitizing the maps in numeric format that permits the application of interpolation (gridding) technique. Therefore, they have been subjected to different techniques of processing and analysis. Remobilization index map: The construction of the (eU$\mathrm{eTh} / 3.5$ ) contour map enables to delineate the limits between the negative contours (leaching) and positive contours (deposition) (Clarke et al.1966) and determine exposure rate and equivalent dose rate. The exposure rate $(\mathrm{E})$ can be calculated from the apparent concentrations of $\mathrm{K}(\%)$, eU (ppm), and $\mathrm{eTh}(\mathrm{ppm})$ using the following expression (IAEA 1991). The exposure rate can be converted to the equivalent dose rate (D) by using the following relation (Grasty et al. 1991):

$$
\begin{gathered}
\mathrm{E} \partial \mathrm{R}=\mathrm{hP} 1 / 4 \text { 1:505 Kð\%P p 0:653 eUðppmP p 0:287 eThðppmP } \\
\text { DðmSv=yearP 1/4 0:0833 Eð } \mu \mathrm{R}=\mathrm{hP}
\end{gathered}
$$


Bayoumi, M. B.

\section{Results and interpretations}

False Color Composite (FCC), Mapping of alteration minerals provides good information about lithology, because rocks are aggregates of minerals. False colour composites (FCC) are used to enhance geologic features for visual analysis (Gad and Kusky, 2006; Massironi et al., 2008; Qari et al., 2008). In a false colour composite method, up to three bands or ratio images need to be selected based on known mineral absorption features. Visual analysis provides guidance for choosing appropriate band combinations for more complex, algorithmic procedures, and gives some preliminary idea about the potential success in mapping the chosen lithologies. They also provide a good medium for communicating results in printed format or when interacting with geologists who do not have extensive remote sensing backgrounds. The false color composite image (bands 7, 4, 2 in RGB), Fig.(3) was interpreted and provided an excellent base map, showing differences that reflect the prevailing geological features, namely line. In false color, the plutonic rocks appear as pale brown, the metavolcanics as dark greenish brown to dark brown, while the andesitic dykes as pale bluish brown to pale brown color.

Fig. 3: Land sat $\mathrm{ETM}+8$ fals colors composite image (band 7, 4, 2 in RGB), of Gabal Suwayqat area, Central Eastern Desert, Egypt.

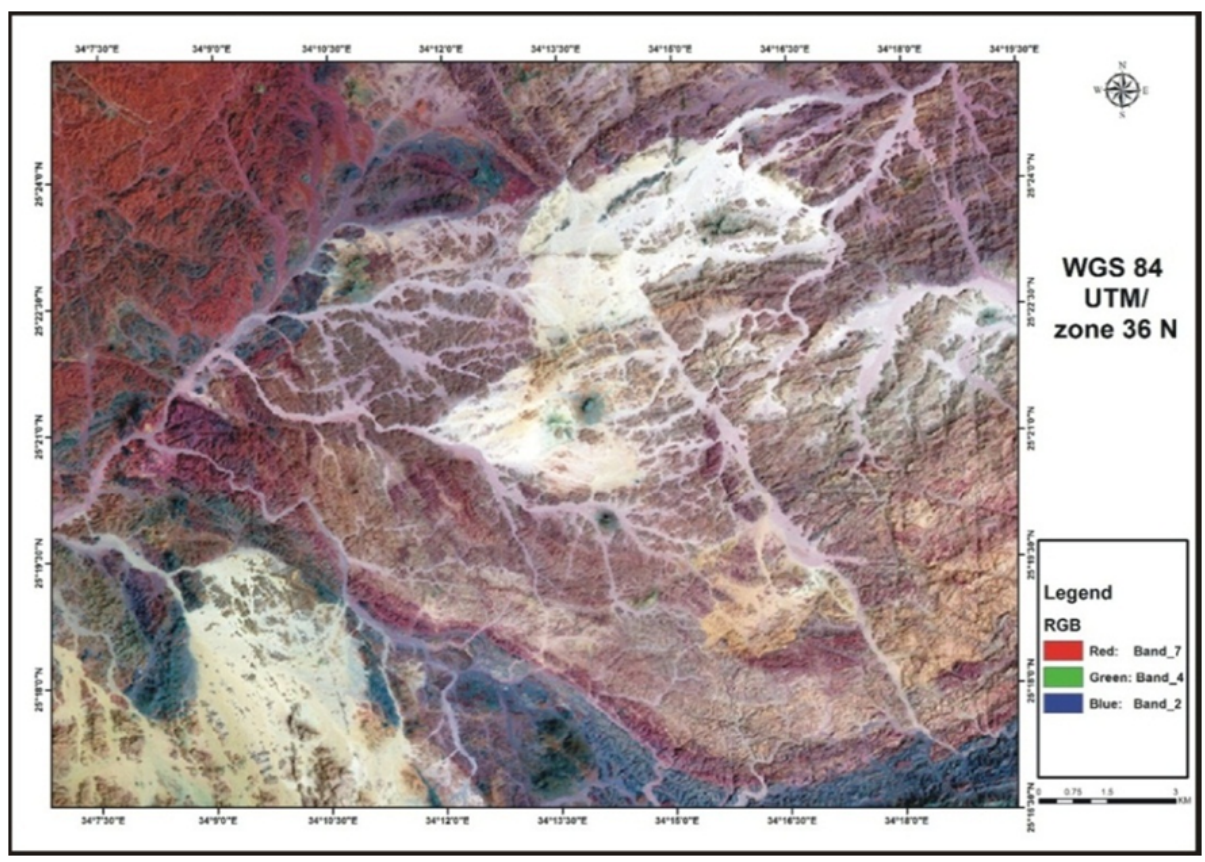

\section{Band ratio images}

The rationing images bands, Figs. (4 and 5) were used for lithological discrimination; moreover, they helped in delimiting disturbed zones, potentially corresponding to hydrothermal alteration haloes. In this ratio images, the monzogranite rocks appear in red color, the metavolcano sedimentary rocks displayed in an interference colors from greenish and blue to green color, intermediate to acidic metavolcanics as bluish reddish brown, olivine gabbro as red, gabbro- dioite rocks in rose color. The serpentinites show mottled brown purple color in a thrust contact with the volcaniclastic metasediments deep brown. Moreover, band ratio image (3/1,5/4and 7/5) in RGB, helped in delimiting disturbed zones, potentially corresponding to hydrothermal alteration zones that may comprise mineralization. In this image, the mafic rocks appear in pale green, hydrothermal alteration zones that may comprise mineralization appears as yellow patches (Fig. 6).

In the processed image after band ratios $5 / 7$ and their combinations in gray color (Fig. 7), minerals in their weathered surfaces. It is clear that both Hammamat sediments and metavolcanics show high content of iron minerals or relatively high ratio of $\mathrm{Fe}_{2} \mathrm{O}_{3}$ and $\mathrm{FeO}$ and low content of clay minerals than younger granitic rocks exposed in the mapped area. Generally, the basic rocks are rich in ferromagnesian and show high proportion of secondary iron minerals in their weathered surfaces, while granitic rocks are rich in silica and their weathering products are kaoline- rich beside silica (El Rakaiby, 1996). 
Application of remote sensing and airborne

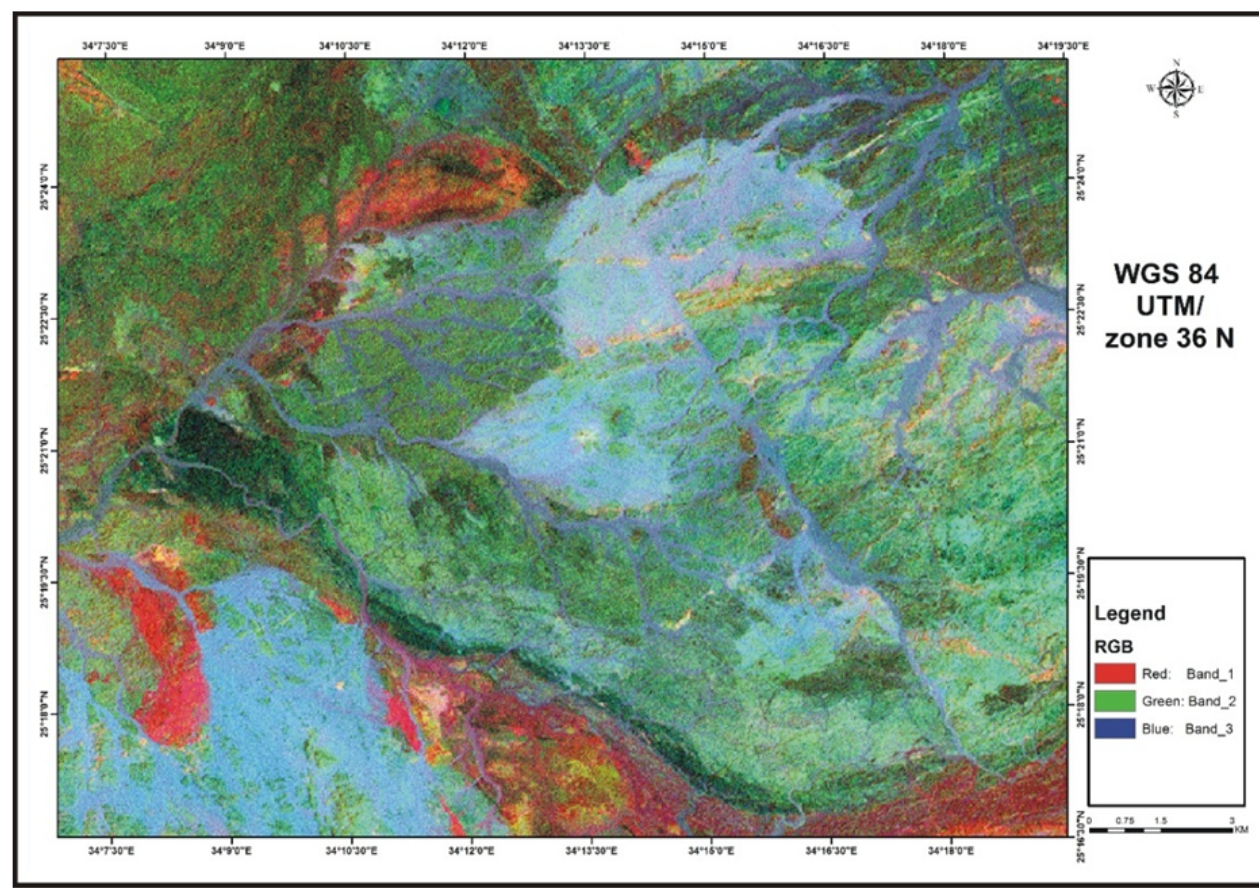

Fig. 4: Land sat

$\mathrm{ETM}+8$ band

ratio image $(5 / 7$,

$4 / 3,3 / 1$ in RGB),

of Gabal

Suwayqat area,

Central Eastern

Desert, Egypt.

Fig. 5: Land sat

$\mathrm{ETM}+8$ band ratio image (5/7, 5/1, 4 in RGB), of Gabal Suwayqat area, Central Eastern Desert.

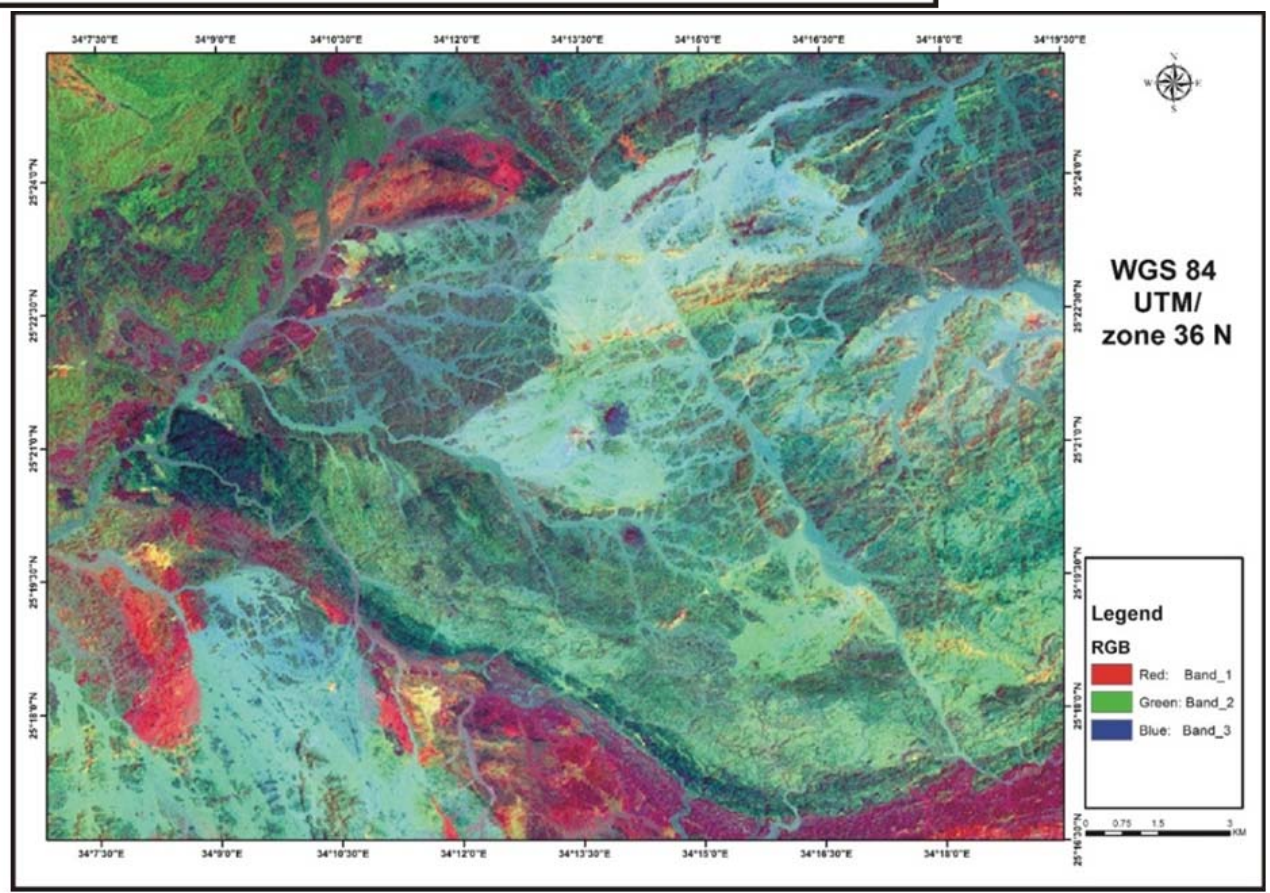

The hydrothermal fluid creates the ore deposit and, also hydrothermal alteration is developed in the host rocks surrounding the ore deposit, and thus the alteration zone is an important feature for mineral exploration.

Different characteristics of the hydrothermal fluid such as temperature, fluid/rock ratio and also the chemical difference of the host rock produce diverse alteration minerals. This causes the development of alteration zoning and provides important information on the hydrothermal fluid and for exploration.

The location of the mineralization can be estimated from the alteration mineralogy and by the mode of occurrence of the alteration zoning. Alteration minerals that create alteration zoning have characteristic absorption patterns, especially in the short wave infrared (SWIR) region (2.0 to $2.5 \mu$ ). 
Bayoumi, M. B.

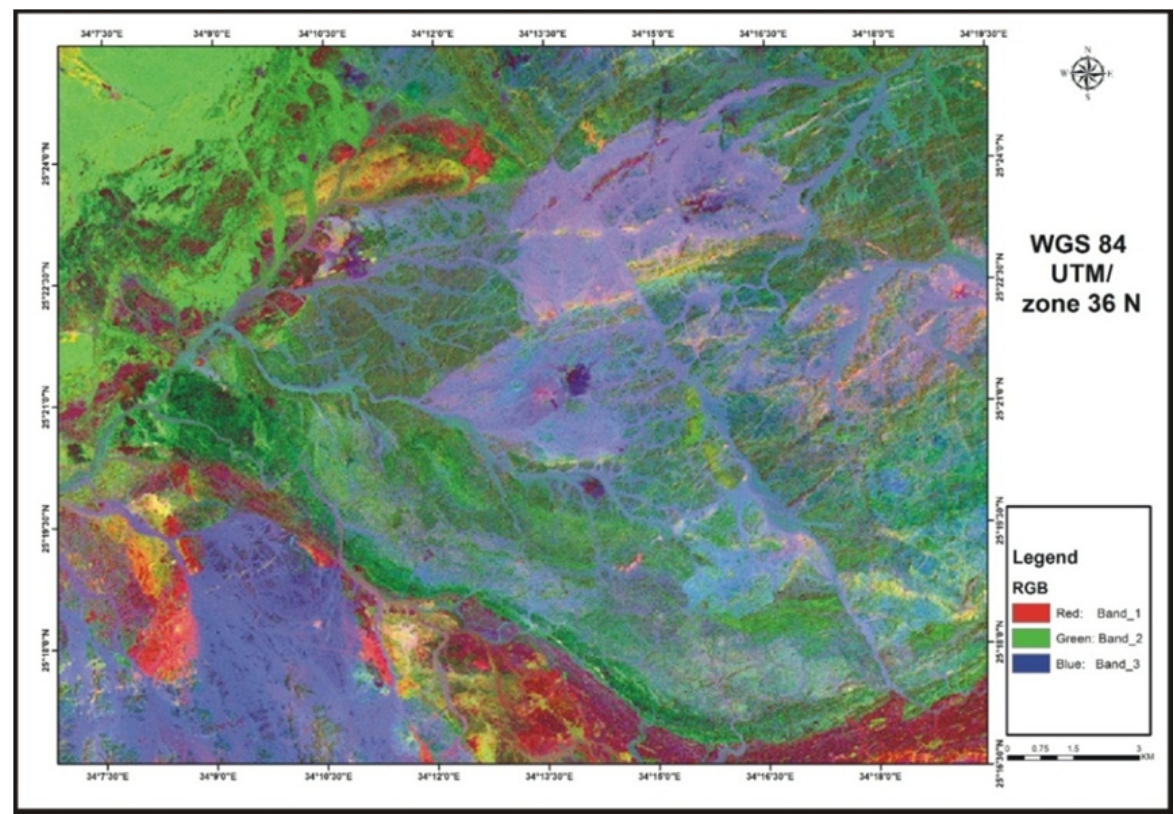

Fig. 6: Landsat

$\mathrm{ETM}+8$ band ratio

image $(3 / 1,5 / 4,7 / 5$ in

RGB) shows

alterations, of Gabal

Suwayqat area,

Central Eastern

Desert, Egypt.

Fig. 7: Landsat ETM +8 band ratio image (5/7in gray color), of Gabal Suwayqat area, Central Eastern Desert.

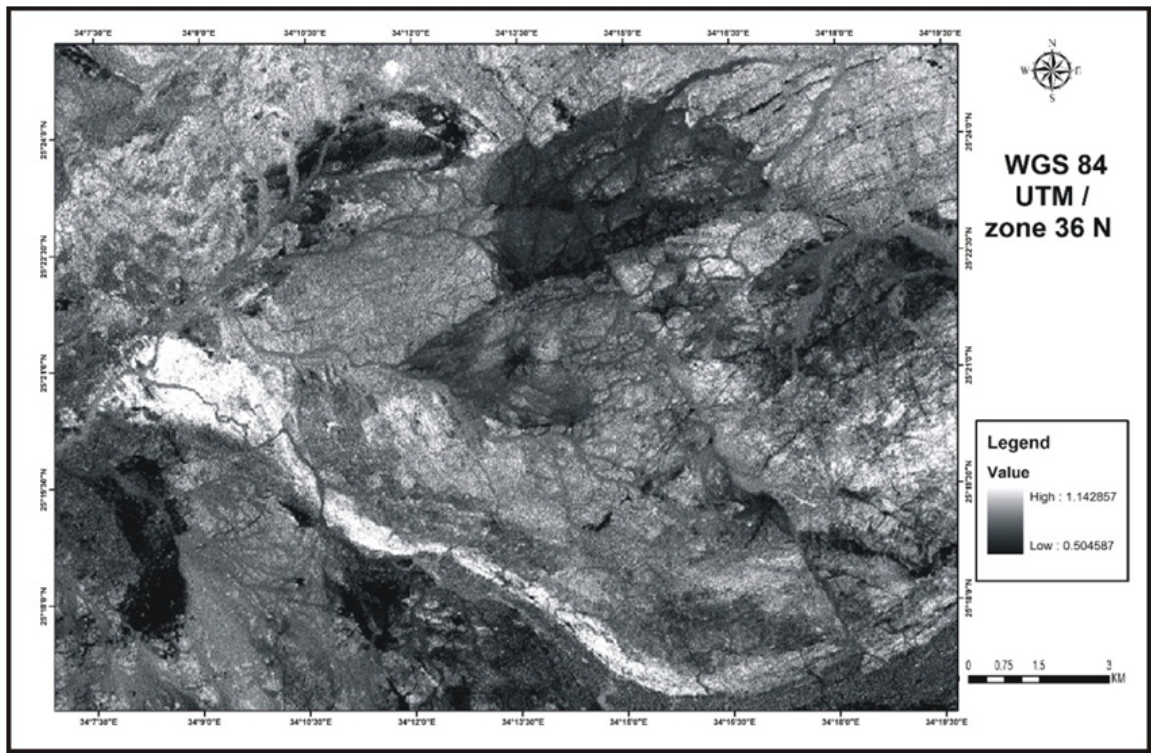

Remote sensing used in mineral exploration of hydrothermal ore deposits often use the spectral features of the alteration minerals at wavelength of 2.0 to $2.5 \mu$ to find alteration zones and identify alteration minerals. Alunite and kaolinite, which are alteration minerals present in advanced argillic alteration, have absorptions at $2.16 \mu$ and $2.2 \mu$ that are created by the aluminum hydroxyl (Al-OH) bond. Sericite, which is a typical alteration mineral in phyllic alteration, has an absorption at $2.2 \mu$ that is also created by the $\mathrm{Al}-\mathrm{OH}$ bond. Chlorite, epidote and calcite, which are present in propylitic alteration, have an absorption at $2.35 \mu$ that is created by the magnesium hydroxyl $(\mathrm{Mg}-\mathrm{OH})$ bond and the carbonic $\left(\mathrm{CO}_{3}\right)$ bond. Iron oxide and hydroxide minerals such as limonite, jarosite and hematite tend to have spectral absorption features in the visible to middle infrared from 0.4 to $1.1 \mu \mathrm{m}$ of the electromagnetic spectrum.

\section{Principal component analysis (PCA)}

The PCA transformation was completed for the ETM+ data to produce the best PCA for the discrimination between rock unites in the study area. These PCA were assigned to the display colors (Red, Green and Blue) respectively to form Pc color composite image. The PCA (Pc2, Pc3 and Pc5) is good to differentiate between the different rocks assemblage of the area as it comprises most of the data reflecting 
Application of remote sensing and airborne

lithologic variations. The image proved to be significant for rock discrimination as well as structural delineation where each rock types has its characteristic color Fig. (8). The lithological interpretation of different rock units in study area according to the spectral characteristic Pc (2,3and 5) can be used for detection and recognition more easily than the FCC, so some rocks in the study area detected and appeared in the PCA process. The granitic rocks are displayed by reddish to orange color while sepentinite rocks are indicated by green color, the metasedementry rocks are displayed by blue color while gabbro rocks are indicated by red color. A modified geological map is produced and Modified after EGSMA, (1989), based on the interpretation of Landsat ETM +8 image. This has been perfected by characterizations of the different rock units and by field checks (Fig. 9).

Fig. 8: Landsat ETM+8 principal components image $(\mathrm{Pc} 2, \mathrm{Pc} 3, \mathrm{Pc} 5$ in RGB) of Gabal Suwayqat area, Central Eastern Desert.
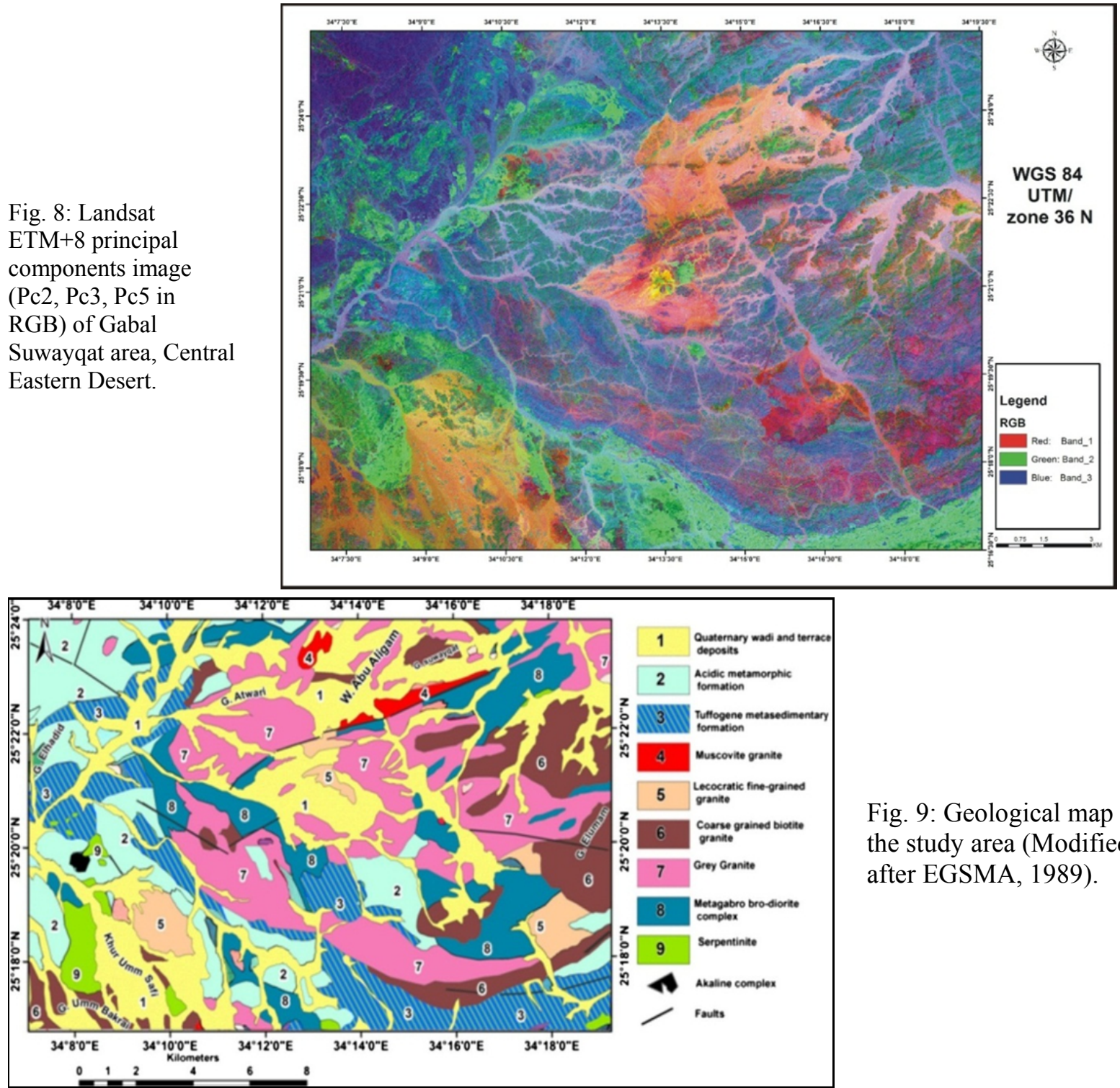

Fig. 9: Geological map for the study area (Modified after EGSMA, 1989).

\section{Gamma-Ray Interpretation}

Potassium (K), uranium (U) and thorium (Th) are the three most abundant, naturally occurring radioactive elements. Potassium is a major constituent of most rocks and is a common alteration element in certain types of mineral deposits. Uranium and thorium are present in trace amounts, as mobile and relatively immobile elements, respectively. Airborne gamma-ray maps reflect the geochemical variations of $\mathrm{K}, \mathrm{eU}$ and $\mathrm{eTh}$ in the upper $30 \mathrm{~cm}$ of the earth's surface. This thin layer is subject to weathering which leads to the loss of the radioelements. Mineralizing process may also alter radioelement 


\section{Bayoumi, M. B.}

content. K may increase in altered rocks. eTh may show increase or decrease during hydrothermal alteration. Detailed interpretation of aerial gamma-ray survey requires the delineation of major geological units and examination of subtle variations with the aid of other data (Charbonneau and Ford 1979). The surface distribution of the radioelements gamma-ray spectrometric maps (Figs. 10, 11, 12, 13, 14, 15, 16, 17 and 18) emphasizes the surface distribution of the radioelements on the area. They are also used to study the geological features with important spatial characteristic. Consequently, the relationship of the contoured radioelement pattern and the distribution of the major lithologic units, including the anomalous ones, have formed the basis for the present interpretation.

\section{The total count contour map (in Ur)}

The total count contour map (Fig. 10) has a wide range of radioactivity ranging from $0.5 \mathrm{Ur}$ to $20 \mathrm{Ur}$. It shows difference in radiometric levels according to the differences in lithologic units. The level $<2 \mathrm{Ur}$ represents the serpentinites, basic metavolcanics, and metagabbro; this level covers a large area extended from the northwestern corner to the southeastern corner of the map, and most of contour lines take the NW-SE direction, while the second level ranging nearly from 2 to 3 Ur represents the total radioactivity of acidic metavolcanic which surrounded the first level as well as the gray granites in the northeastern corner of the map. The third level (3-4.5 Ur) shows relative moderate radioactivity recorded over the wadi sediments which mainly derived from all granitoid rocks in the center and east of the map. This level shows E-W trend in the contour lines. Wadi sediments around the younger granites represent the fourth level (4.5-6 Ur). The fifth level ( $>6 \mathrm{Ur}$ ) was recorded in many localities in the study area over the younger granites which are distributed as isolated bodies aligned around the big batholith of younger granites (fine-grained biotite granites as G. Elumrah and G. Suwiqate) or made anomalous part as in case of the medium-grained biotite granite in the southwest- ern part of the study area (reaches to $20 \mathrm{Ur}$ ).

Fig. 10: Total count radiometric map, in $\mathrm{Ur}$ $(\times 10)$, at Gabal a Suwayqat area, Central Eastern Desert.

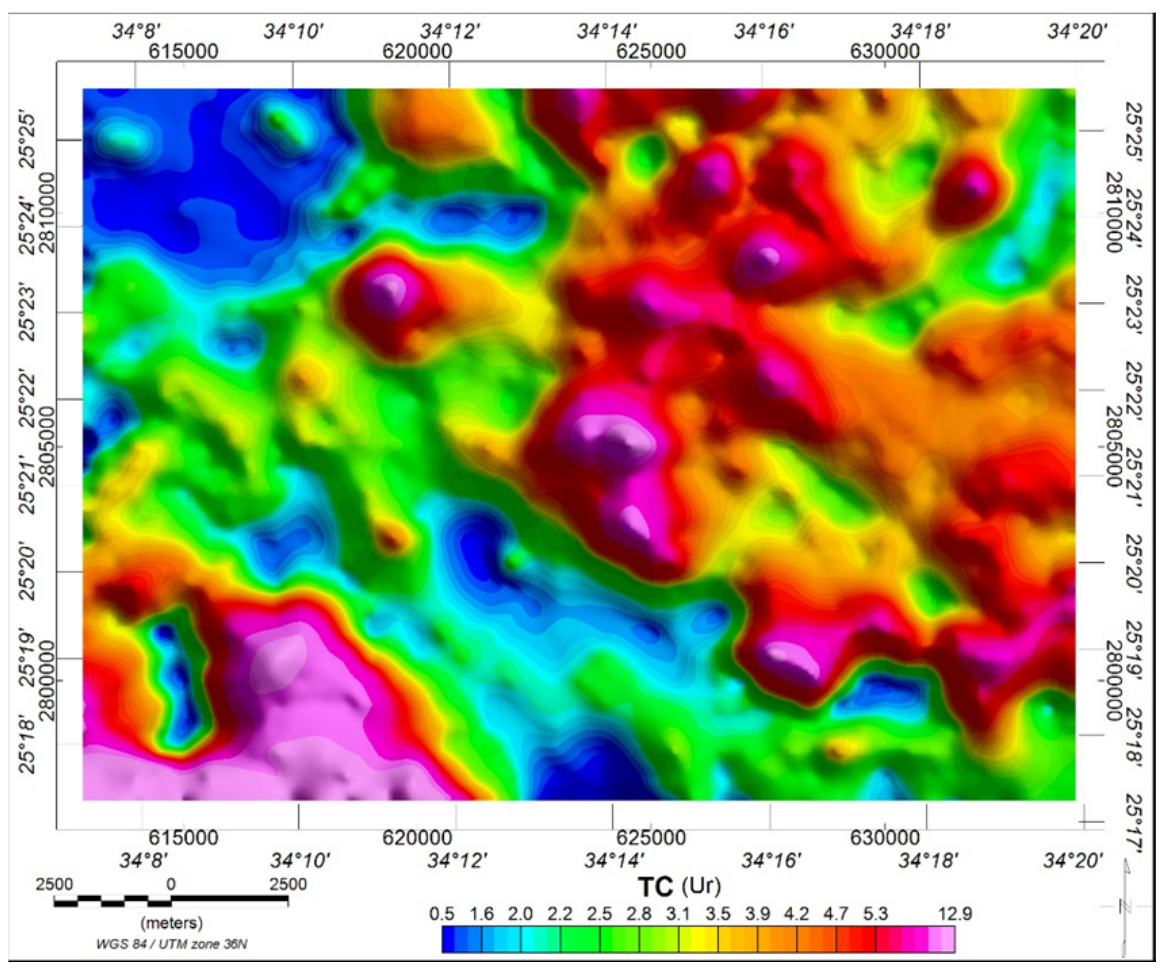

\section{Potassium contour map (in \%)}

The map (Fig. 11) shows similarity to the total count map in the corresponding geologic units and levels of radioactivity, but the highest level is related to the fine-grained biotite gran- ites. The range of the four levels was $0-0.6,0.6-1,1-1.8$, and $1.8-2.6 \%$, respectively, and in anomalous zone the reading reaches $3.8 \%$. 
Application of remote sensing and airborne

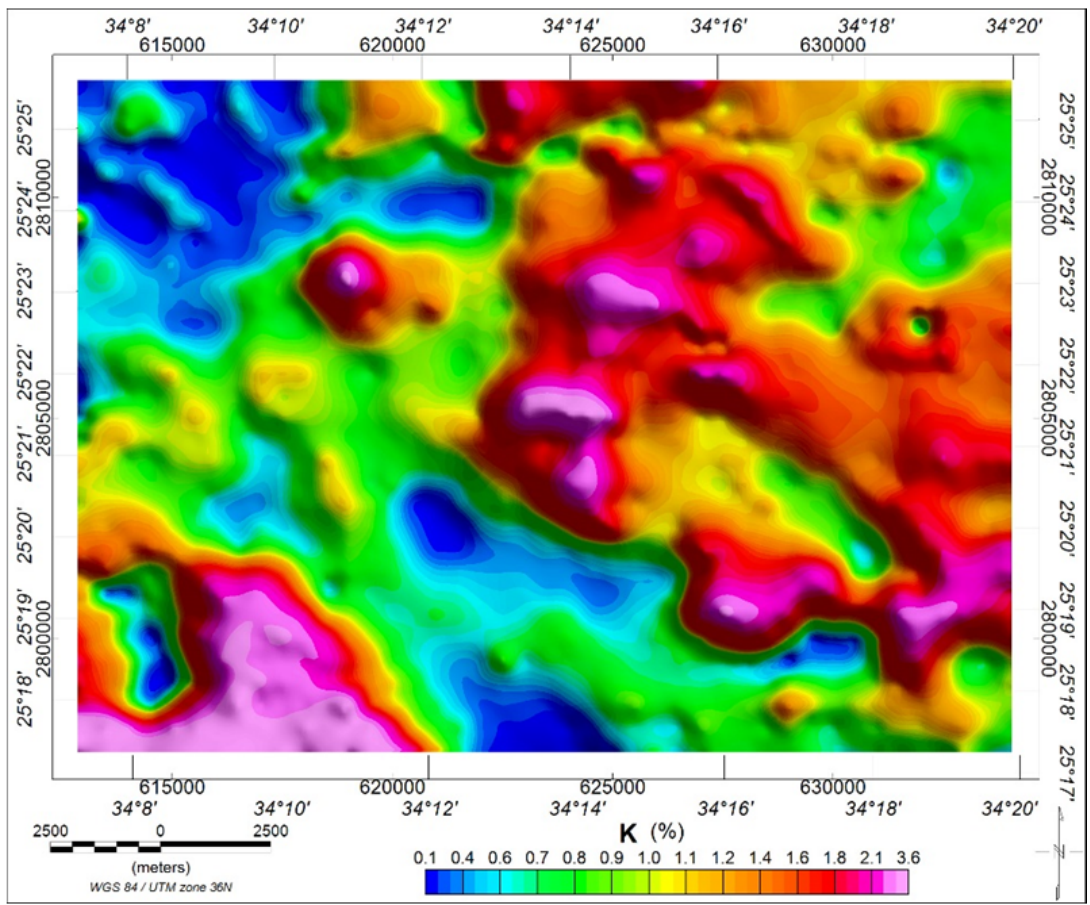

Fig. 11: Potassium percent radiometric map, in $\operatorname{Ur}(\times 10)$, at Gabal a Suwayqat area, Central Eastern Desert.

\section{Equivalent uranium contour map (in ppm)}

This map (Fig. 12) shows four levels of radioactivity, each of which represents one or more lithologic units. The very low level $>1 \mathrm{ppm}$ represents the metavolcanics, metagabbro, and serpentinites. The low level of uranium radioactivity, ranging between 1 and $1.6 \mathrm{ppm}$, was recorded over the gray granites. The moderate level ranging between 1.6 and $3 \mathrm{ppm}$ was re- corded over the sediments of younger granitic origin, while the fourth level was $>3 \mathrm{ppm}$ and reaches to $7 \mathrm{ppm}$ in anoma- lous parts recorded over the younger granite (fine- and medium-grained biotite granites) in the southwestern and cen- tral parts of the area. These anomalous zones take NW-SE direction.

Fig. 12: Equivalent Uranium map, in Ur $(\times 10)$, at Gabal a Suwayqat area, Central Eastern Desert

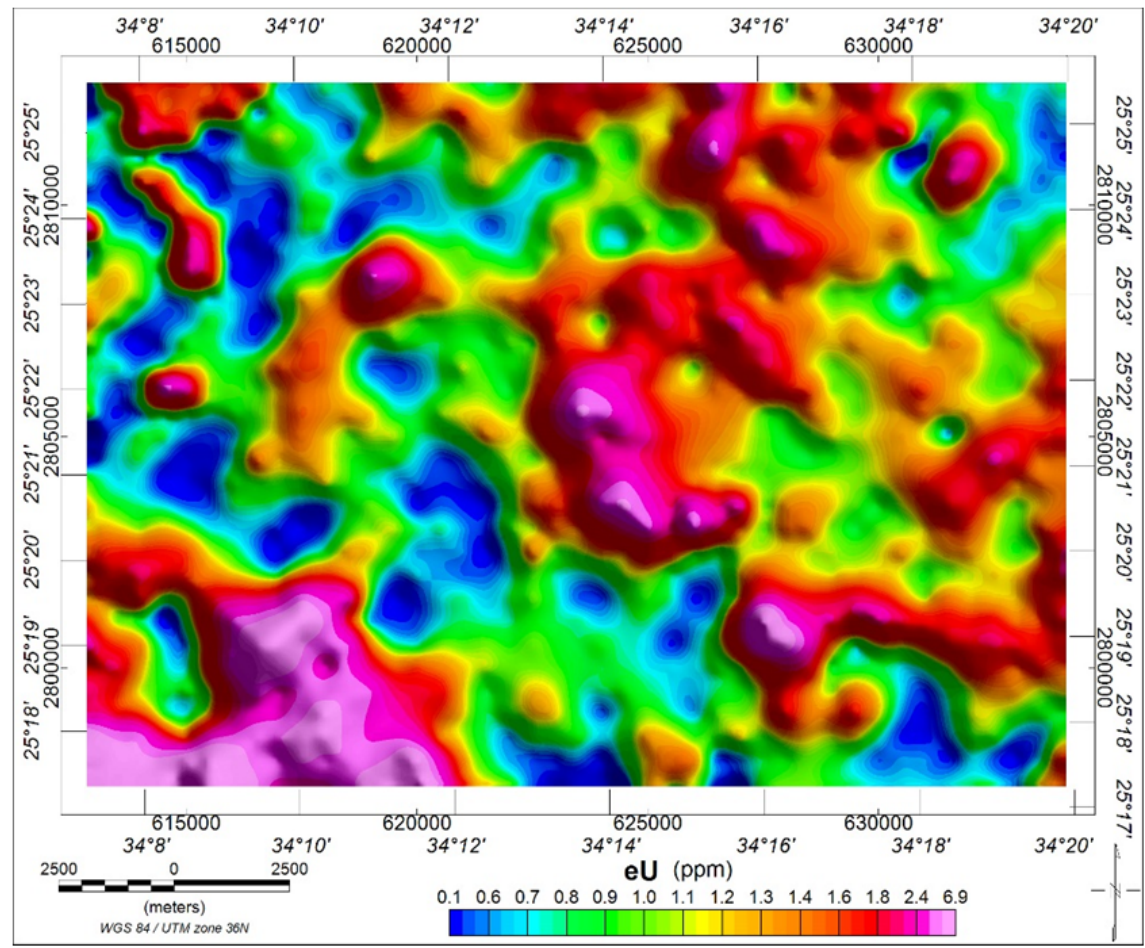




\section{Bayoumi, M. B.}

\section{Equivalent thorium contour map (in ppm)}

This map (Fig. 13) shows four levels for the different lithologic units, where the value $<2 \mathrm{ppm}$ eTh represents the lowest level records over the basic metavolcanics, metagabbro, and serpentinites especially in the western part of the study area. The second level ranging between 2 and $4 \mathrm{ppm}$ eTh represents the gray granites and acidic metavolcanics. This level covers the largest area of the map. The acidic wadi sediments surrounded the younger granite bodies represent the third level that ranges between 4 and $8 \mathrm{ppm}$ eTh. The pink granite repre- sents the fourth level starting from $8 \mathrm{ppm}$ and reaching $15 \mathrm{ppm}$ eTh, showing high anomalous zones that are associated mainly with structural elements trending NE-SW and NW-SE direc- tions as well as minor presence in $\mathrm{E}-\mathrm{W}$ direction.

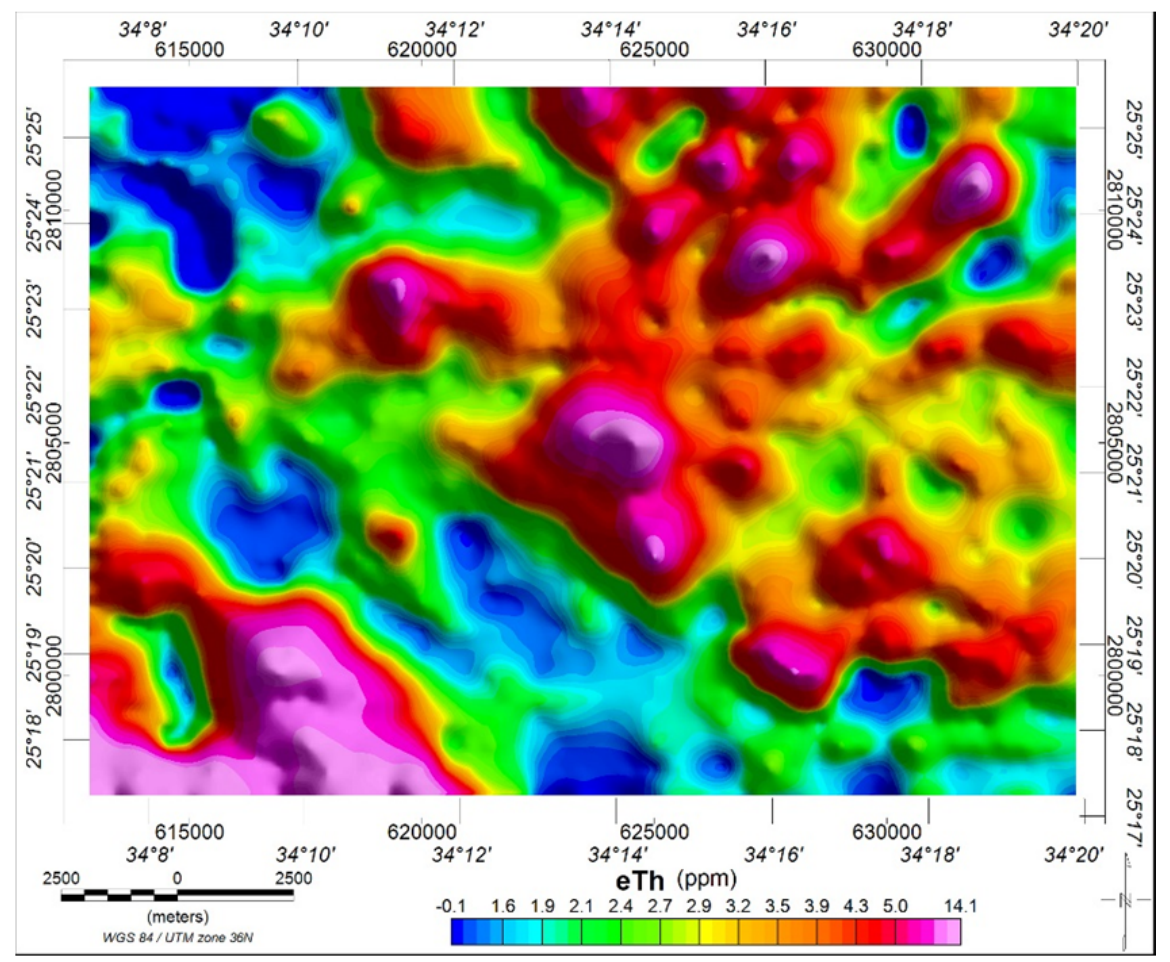

Fig. 13: Equivalent Thorium map, in Ur $(\times 10)$, at Gabal a Suwayqat area, Central Eastern Desert.

\section{eU/eTh ratio contour map}

This map (Fig. 14) shows that the study area has thorium con- tent more than uranium content except two sites of gabbroic rocks in the northeast and southeast of the area. Some areas show this ratio range from 0.5 to 1 recorded over the metagabbro and acidic metavolcanics. This may due to some acidic dikes that invaded these rocks in those areas.

\section{eU/K ratio contour map}

This map (Fig. 15) shows that the study area has eU/K ratio content $>1$ in the basic rock locations, while this ratio was less than 1 over the granitic rocks (gray granites and pink granites) and acidic metavolcanics.

\section{$\mathrm{eTh} / \mathrm{K}$ ratio contour map}

This map (Fig. 16) shows that the study area has higher thorium content than potassium content. This ratio increased over the basic rocks and reached maximum value over the metavolcanics in the northwestern part of the area, while the acidic rocks have the lowest $\mathrm{eTh} / \mathrm{K}$ ratio. This ratio decreased with the increase of the acidity where the potassium content is increased. 
Application of remote sensing and airborne

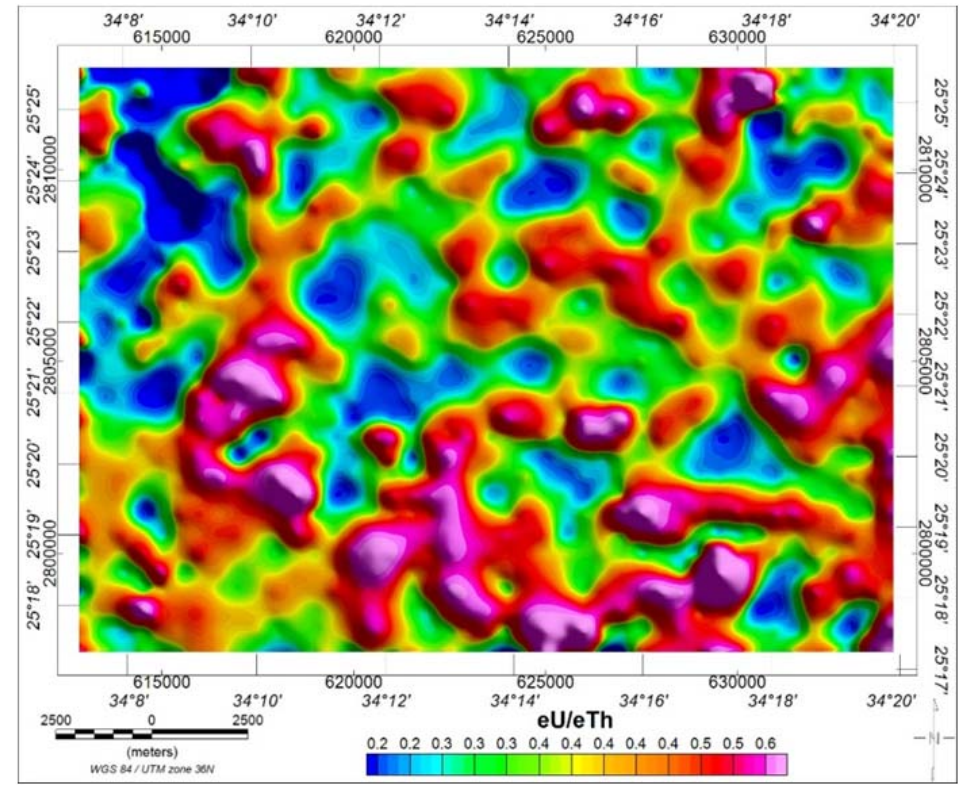

Fig. 14: eU/eTh ratio

map, at Gabal a

Suwayqat area, Central

Eastern Desert, Egypt

Fig. 15: eU/K ratio map,

at Gabal a Suwayqat

area, Central Eastern

Desert.
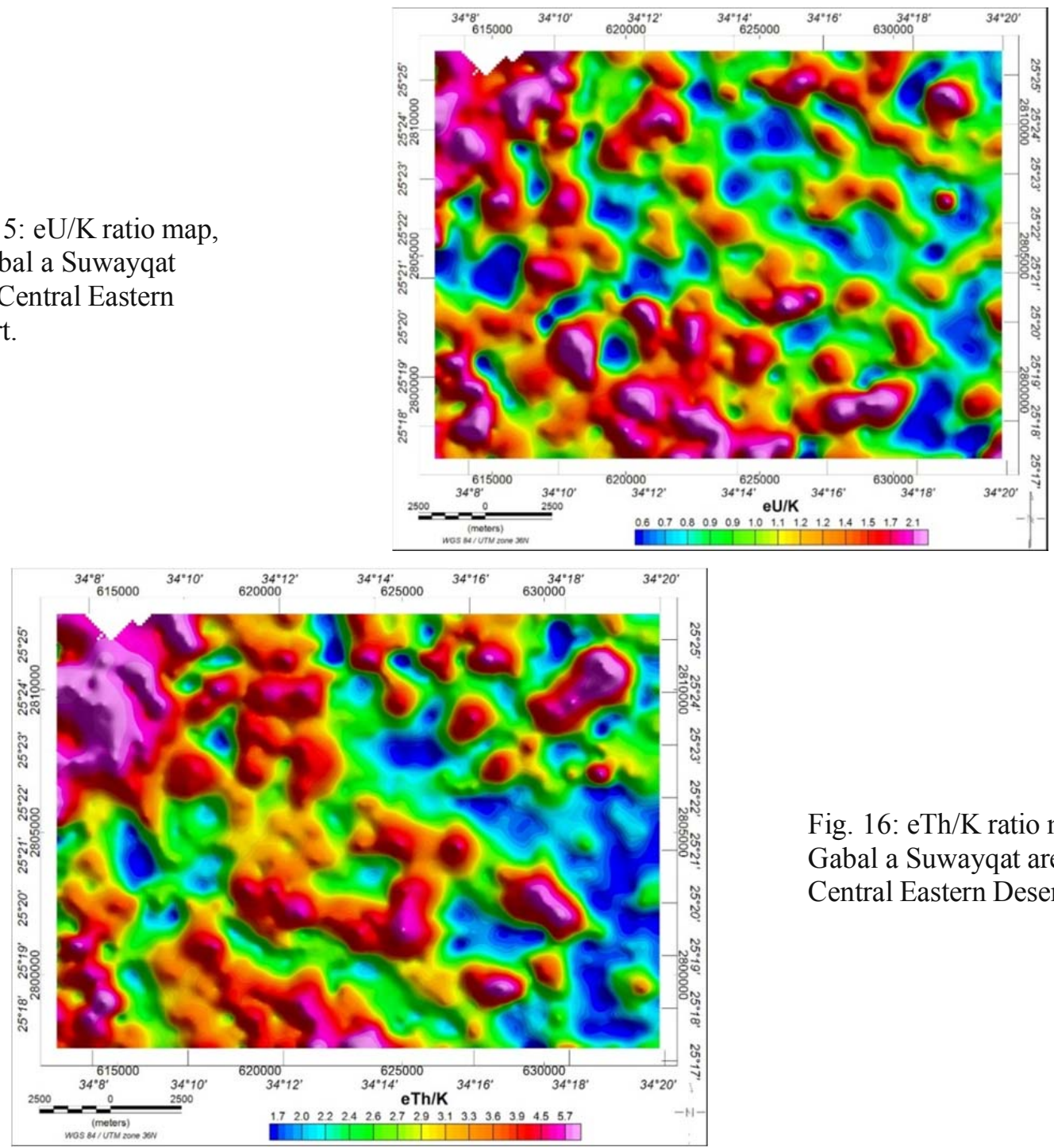

Fig. 16: eTh/K ratio map, at Gabal a Suwayqat area, Central Eastern Desert. 


\section{Bayoumi, M. B.}

\section{Uranium migration index contour map}

(eU-eTh/3.5) contour map in parts per million (Fig. 17) is con- sidered as an index for uranium migration in and out of the different lithologic units especially the granitic ones. The locations of negative readings (leaching parts) show that urani- um is migrated out. They are found northwest and northeast of the study area as well as some localities in the center of the area. The rocks in the previous parts are mainly basic beside the gray granites and pink granites, while the positive reading area and trends NE-SW direction, and the second wadi is located in the southeast of the area and trends NW-SE direc- tion. The center of this wadi shows the highest precipitation parts inside the fine-grained granites in these parts. The third site of precipitation is recorded along and around Khur Umm Safi especially over the medium-grained biotite granites in the east of this khur. Khur Umm Safi lies in the southwest of the map and trends NW-SE direction.

Fig. 17: Mobility eU(eTh/3.5) map, at Gabal a Suwayqat area, Central Eastern Desert.

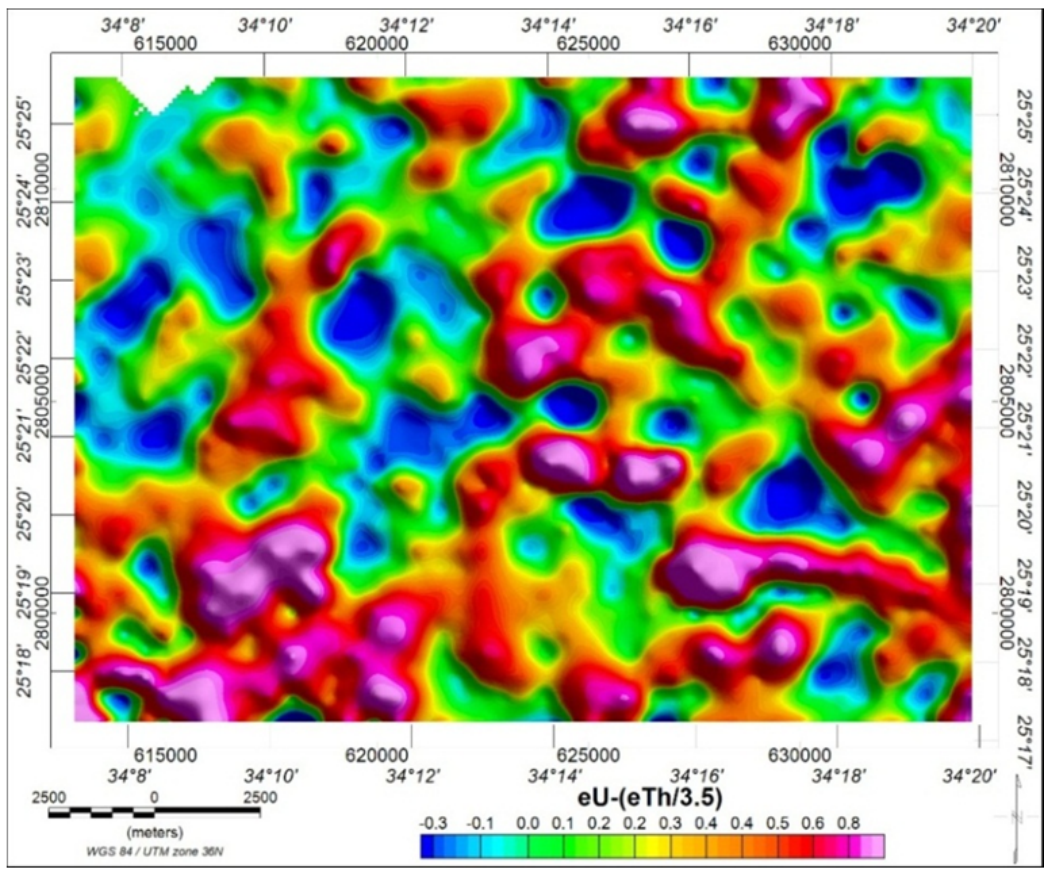

\section{Dose rate at Gabal a Suwayqat area}

The International Commission of Radiological Protection (ICRP) has recommended that no individual should receive more than $1 \mathrm{mSv} / \mathrm{year}$ from all natural and artificial radiation sources in his or her environment (IAEA 2000). The exposure rate (E) can be calculated from the apparent concentrations of K (\%), eU (ppm), and eTh (ppm) using the expression (IAEA, 1991):

$$
\mathrm{E}(\mu \mathrm{R} / \mathrm{h})=1.505 \mathrm{~K}(\%)+0.653 \mathrm{eU}(\mathrm{ppm})+0.287 \mathrm{eTh}(\mathrm{ppm})
$$

The exposure rate can be converted to the equivalent dose rate by using the following relation (Grasty et al., 1991): $\mathrm{D}(\mathrm{mSv} / \mathrm{y})=0.0833^{*} \mathrm{E}(\mu \mathrm{R} / \mathrm{h})$, It is cleared from (Fig. 18) that the area has a low level of average dose rate, and it does not exceed the safe limit $(1.0 \mathrm{mSv} /$ year $)$. Therefore, study area is not harmful to the individuals. Further systematic measurements introduce better information about the radiation levels to be reference in case of any possible environmental nuclear pollution in the future, in this part of Egypt.

\section{Gamma-ray Spectrometric Ternary Image}

Ternary images provide a simultaneous display of the three parameters $\mathrm{K}, \mathrm{U}$ and Th Ratios from ground gamma-ray spectrometry measurements on one image and facilitate, discriminate and delineate the lithological units of the studied area (Fig. 19). The radioelement ternary image combines the data of $\mathrm{K}$ (in blue), eTh (in green), and eU (in red). Obviously, different phases of granites are characterized by an increase of the radioactivity content of the three radioactive elements. Consequently, they appear nearly white in colour. Meanwhile, the radioactivity contents of the three elements decrease sharply 


\section{Application of remote sensing and airborne}

around the granites, which are characterized by dark colors as a result of Wadi sediments and country rocks. The highest level (white color) that represents a source of uranium, nearly without potassium or thorium are associated with the monzogranites and circular-shaped, located at the South western part of the studied area, in addition to another one, located in its eastern part, which are associated with alkali feldspar granites.

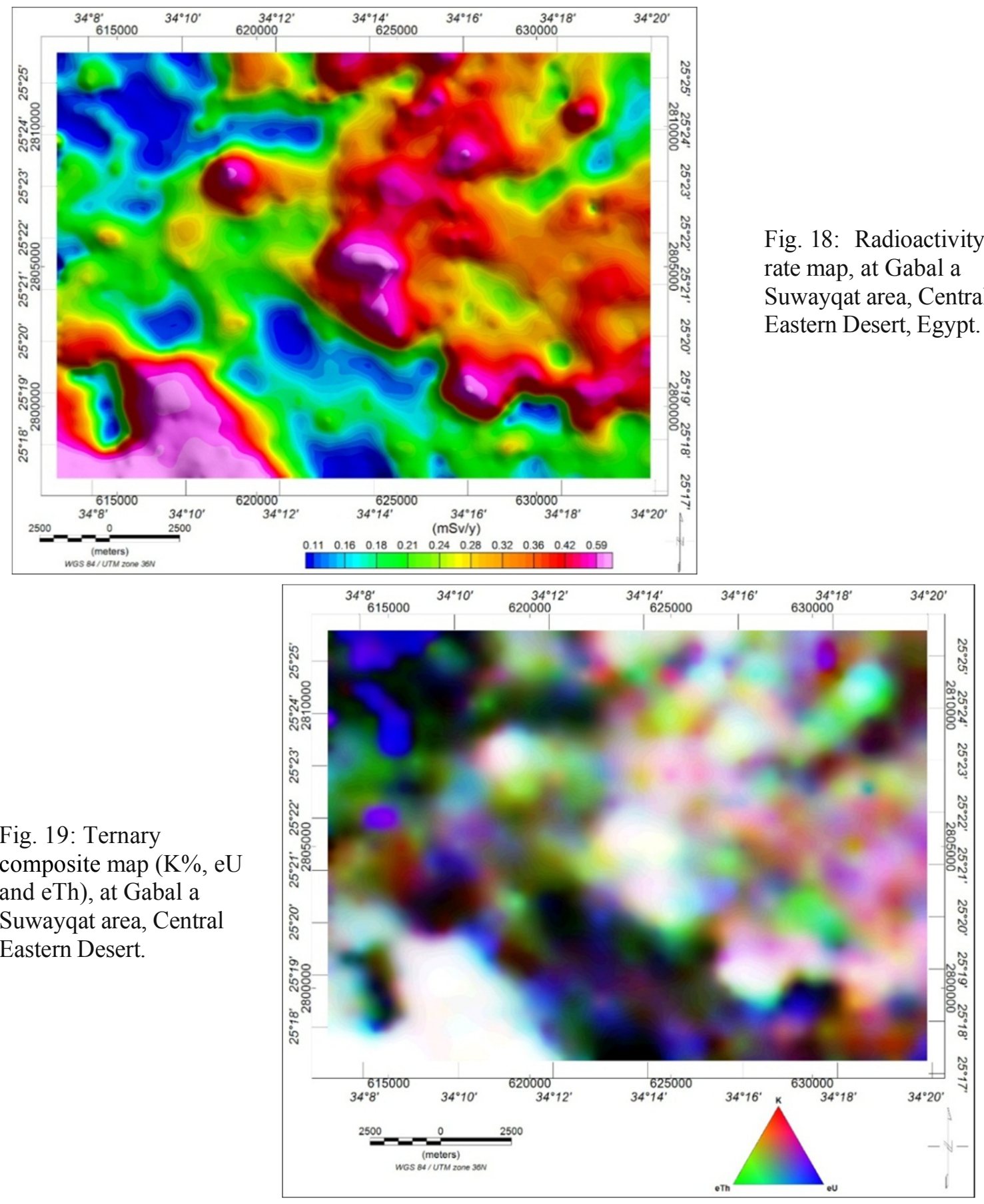

\section{CONCLUSION}

Image enhancement techniques are applied to the subset $\mathrm{ETM}^{+} 8$ data of studied plutons. These techniques generated several products of image processing ranging from color composite images, band ratio image and color band ratios images. These techniques have been used successfully in lithological discrimination between different rock types. Landsat ETM+ false color composite image (bands 7, 4, 2) 


\section{Bayoumi, M. B.}

was used for discriminated between different rock types and gives an excellent base map for the investigated area. Band ratios $(5 / 7,4 / 3,3 / 1),(5 / 7,5 / 1,4)$ and $(3 / 1,5 / 4,7 / 5)$ in red, green and blue respectively, were created from the Landsat ETM + data to discriminate the exposed rocks in the study area on the basis of color differences due to mineralogical composition. Band ratio 5/7 in gray color for exposed rocks rich in hydroxyl-bearing phases such as clay minerals (Pieters and Engler, 1993).

The iron and manganese solutions are diffused outward from the joints staining the rock mass giving it a reddish and dark appearance. The basic rocks are rich in ferromagnesian and show high proportion of secondary iron minerals in their weathered surfaces, while granitic rocks are rich in silica and their weathering products are kaolin rich beside silica denoted that the ETM+ bands 1 to 4 contain information on iron minerals. Generally, Recognition of hydrothermal altered rocks associated with mineral deposits was carried out using image-processing techniques such as band ratio images. The hydrothermal minerals that detected by the Landsat image processing of the data of selected areas could by classified into two groups: hydroxyl (clay minerals) and hydrated mineral (alunite and jarosite) detected by band ratio 5/7.

The main results of the radioactive studies that the granitic rocks have the highest contents of radioactive elements (total count, $\mathrm{K} \%$, eU and eTh) where the mean contents of this rock unit are $20 \mathrm{Ur}$, $3.6 \%, 6.4 \mathrm{ppm}$, and $14 \mathrm{ppm}$, respectively. The equivalent thorium contents are more than equivalent uranium contents in most of lithologic units in the study area. The pink granite and most of the rock units in the study area are relatively eTh-rich, as $\mathrm{eTh} / \mathrm{K}$ ratio $>2$ while the eU/eTh $<1$, which means that this granite is relatively depleted in uranium. The area has low level of average dose rate, and its dose not exceed the safe limit (1.0 mSv/year). The integration of radiospectrometric and image processing results reveals that the NW-SE and WNW-ESE are the main faults that affect the distribution of the radioactive elements.

\section{REFERENCES}

Abd-Elhadi, H. M. (1978): Aero radiometric data and its relation to the regional geology of Bakriya area, Eastern Desert, Egypt. Ph. D. Thesis, Faculty of Science, Cairo University, Egypt, 259 p.

Abu-Elnaga, H. S and Al-Garni, A. M. (2015): Airborne gamma- ray spectrometric and magnetic studies of Wadi Um Geheig- Wadi Abu Eligam area, Central Eastern Desert, Egypt. Arab .J. Geosc., 8:88118833.

Aero-Service, (1984): Interpretation report of airborne gamma-ray spec- trometer and magnetometer survey of the Eastern Desert of Egypt. Aero-Service Division, Western Geophysical Company of America, USA, pp 1-127.

Clarke, S. P Jr, Peterman, Z. E and Heier. K. S. (1966): Abundances in uranium, thorium and potassium. In: Handbook of physical constants. Geological Society of America, Memoir 97, 521-541.

Charbonneau, B. W. and Ford, K. L., (1979): Discovery of Two Uranium Occurrences in Paleozoic Sedimentary Rocks at South March, Ontario and South Maitland, Nova Scotia by Airborne Gamma-ray Spectrometry and Comparison with Surveys over Precambrian Terrain; Journal of the Canadian Society of Exploration Geophysicists, 15 (1), 54-76.

Di Tommaso, I., Rubinstein, N., (2007): Hydrothermal alteration mapping using ASTER data in the infernally porphyry deposit, Argentina. Ore Geol. Rev. 32, 275-290.

El Rakaiby, M. L. (1996): Discrimination of igneous rocks using digital thematic mapper data in southern Sinai, Egypt. Geocrato Inter., Hong Kong, II, 4, 61- 69.

El-Shazly, E. M. (1977): The geology of the Egyptian region. In: Narin AEM, Kanes WH, Stehli FG (eds) The ocean basins and margins. Plenum Publishing Corporation, 379-444.

Garven, G., Appold, M. S., Toptygina, V. I., Hazlett, T. J., (1999): ydrogeologic. modeling of the genesis of carbonate-hosted lead-zinc ores. J. Hydrol. 7, 108-126.

Gad, S. and Kusky, T. M., (2006): Lithological mapping in the Eastern Desert of Egypt, the Barramiya area, using Landsat Thematic Mapper (TM). J. Afr. Earth Sci. 44, 196-202.

Geological Survey of Egypt, (1989): Geological map of basement rocks of Gabal Um Gheig, Egypt, scale 1:100,000. Geol. Surv. Egypt, Cairo, Egypt.

Grasty, R. L. Holman, P. B and Blanchard, Y. B. (1991): Transportable calibration pads for ground and airborne gamma-ray spectrometers. Geological Survey of Canada, Paper 90-23. 24 p. 
Application of remote sensing and airborne

Hussein, A. A. (1990): Mineral deposits, In: R. Said (ed.), The geology of Egypt. Balkema, Rutterdam, $734 \mathrm{p}$.

International Atomic Energy Agency (IAEA) (1991): Airborne gamma- ray spectrometer surveying. IAEA, Vienna, Austria, Technical Report Ser. 323, 97p.

International Atomic Energy Agency (IAEA) (2000): $5^{\text {th }}$ Inter.1 Conf. on High Level of Natural Radiation, Munich (Waste solutions, 42

Johnson, P. R., Andresen, A., Collins, A. S., Fowler, A. R., Fritz, H., Ghebreab, W., Kusky, T., Stern, R. J., (2011): Late Cryogenian- Ediacaran history of the Arabian-Nubian Shield: a review of depositional, plutonic, structural, and tectonic events in the closing stages of the northern East African Orogen. J. Afr. Earth Sci. 61,167-232.

Kamel, A. F and Abdelhadi, H. M. (1992): Photogeological and geophysical stud- ies on the basement rocks in Wadi Elmiyah, Eastern Desert, Egypt. J Afr Earth Sci 15(314), 385-398.

Nesbitt, B. E., (1992): Orogeny crustal hydrogeology and the generation of epigenetic ore deposits in the Canadian Cordillera. Mineral. Petrol. 45, 153-179.

Oliver, J., (1986): Fluids expelled horizontally from orogenic belts: their role in hydrocarbon migration and other geologic phenomena. Geology 14, 99-102.

Sabins, F. (1997): Remote Sensing Principles and Interpretations. W. H. Freehamand Co., NewYork, $3^{\text {rd }}$ ed., 494p.

Rabie, S. I. and Ammar, A. A., (1990): Delineation of geological structures from aeromagnetic data using some integrated interpretation techniques, El-Missikat and El-Erediya granitic plutons, Central Eastern Desert, Egypt. The $8^{\text {th }}$ Annual Meeting of the Egyptian Geophys. Soc. (EGS), Cairo, Egypt.

Rowan, L. C., Wetlaufer, P. H., Goetz, A. F. H., Billingsley, F. C. and Stewart, J. H., (1974): Discrimination of rock types and detection of hydrothermally altered areas in south-central Nevada by the use of computer-enhanced ERTS images. US Geol. Surv. Prof. Paper 883, 35 pp. 


\section{Bayoumi, M. B.}

تطبيق بيانات الاستثعار عن بعد وقياسات أشعة جاما الطيفية الجوية لتحديد نطاقات التحول بمنطقة جبل السويقات، وسط الصحراء الثرقية-مصر.

\section{مصطفى بيومي مصطفى}

هيئة المواد النووية -القاهرة - مصر

الخلاصة

تهدف الدراسة الحالية استخدام التكامل بين معطيات بيانات الاستشعار من البعد والقياسات الجوية الطيفية لأشعة جاما لاستتباط العلاقات بين الوحدات الصخرية والمحتوى الإشعاعي بمنطقة جبل السويقات بوسط الصحراء الثرقية، مصر ـ أظهرت

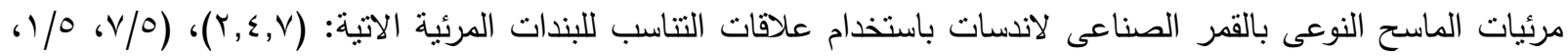

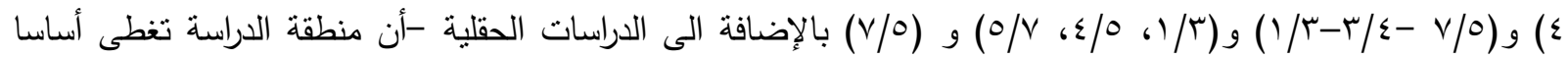
بالوحدات الصخرية الآتية من الأقدم إلى الأحدث: صخور السربيتينات القديمة، صخور الجابرو ديورايت، صخور الجرانيت القديمة، صخور الجرانيت البيوتينى ذات اللون الرمادى ، صخور الجرانيتات المسكوفيتى، تكوينات من الصخور الحامضية و

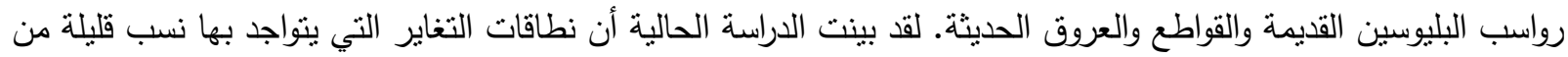
المواد الاشعاعية يمكن ثمييزها عن الوحدات الصخرية المختلفة بناءً على نطاقات التحول في الصخور التي نظهر في نون مختلفة داخل تحليلات صور الاندسات وذلك نتيجة لاختلاف نسب وجود المعادن الحامضية والمافية في تلك الوحدات

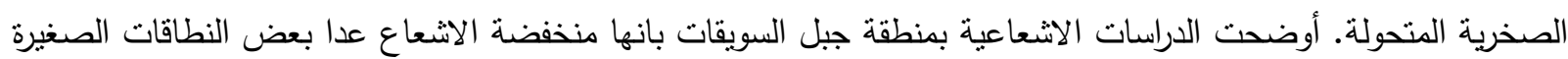
والمحدودة التىى ترتبط بالقواطع الحديثة والفوالق الجيولوجية نتيجة عوامل النقل والترسيب بها بما يجعل من منطقة الدراسة منطقة باتها

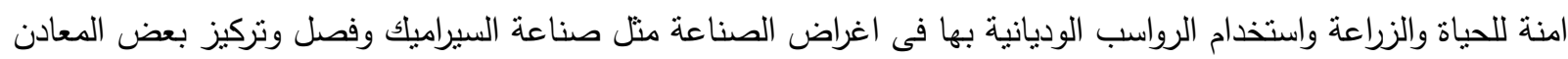

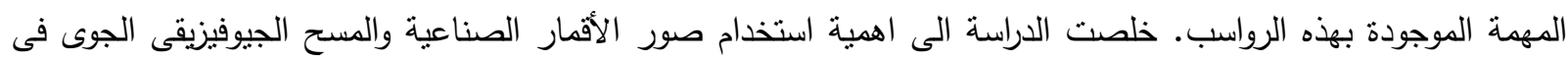

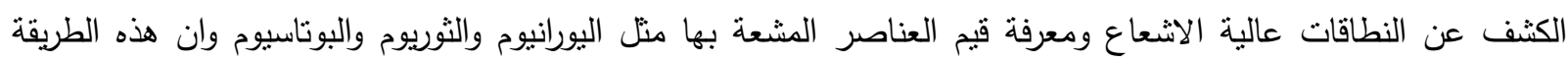

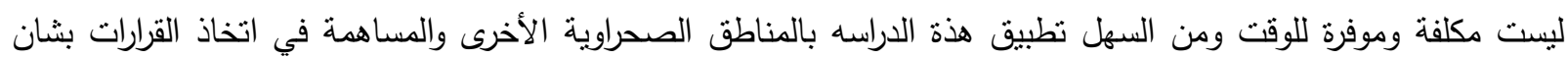
تتمية المناطق النائية زراعيا وصناعيا وبشريا. 